\title{
Dam pre-release as an important operation strategy in reducing flood impact in Malaysia
}

\author{
Nurul Hidayah Ishak ${ }^{1 *}$, and Ahmad Mustafa Hashim ${ }^{1}$ \\ ${ }^{1}$ Department of Civil and Environmental Engineering, Faculty of Engineering, Universiti Teknologi \\ PETRONAS, 32610 Bandar Seri Iskandar, Perak, Malaysia
}

\begin{abstract}
The 2014 flood was reported to be one of the worst natural disaster has ever affected several states in the northern part of Peninsular Malaysia. Overwhelming rainfall was noted as one of the main factors causing such impact, which was claimed to be unprecedented to some extent. The state of Perak, which is blessed with four cascading dams had also experienced flood damage at a scale that was considered the worst in history. The rainfall received had caused the dam to reach danger level that necessitated additional discharge to be released. Safety of the dams was of great importance and such unavoidable additional discharge was allowed to avoid catastrophic failure of the dam structures. This paper discusses the dam pre-release as a significant dam management strategy in reducing flood impact. An important balance between required dam storage to be maintained and the risk element that can be afforded is the crucial factor in such enhanced operation strategy. While further possibility in developing a carefully engineered dam pre-release strategy can be explored for dam operation in Malaysia, this has already been introduced in some developed countries. Australia and South Africa are examples where pre-release has been practiced and proven to reduce flood risk. The concept involves controlling the dam lake level throughout the year, in reference to the rainfall data and the hydrological properties for the catchment area of the dams. Plentiful data analysis need to be done in contemplation of producing the optimal pre-release model. The amount of heavy rainfalls received is beyond human control but the distribution of the discharge from the dams can be further managed with the appropriate pre-release strategy.
\end{abstract}

\section{Introduction}

Flood is one of the main disasters faced by countries worldwide. Some of the natural disaster faced worldwide includes floods, volcanic eruptions, earthquakes, tsunamis and other geologic processes. Since Malaysia is not located within the active volcanic plates and tornado alley, flood is one of the main disasters that keep the government concerns almost every year. According to Emergency Events Database (EM-DAT), a global database on natural and technological disasters, flood is the most frequent disaster that happened in

\footnotetext{
* Corresponding author: nurulhidayahishak@gmail.com
} 
Malaysia, which constitutes $48 \%$ of total disaster occurrences [1]. Fig. 1 shows the frequency of natural disasters that occurred in Malaysia, from 1965 to 2016.

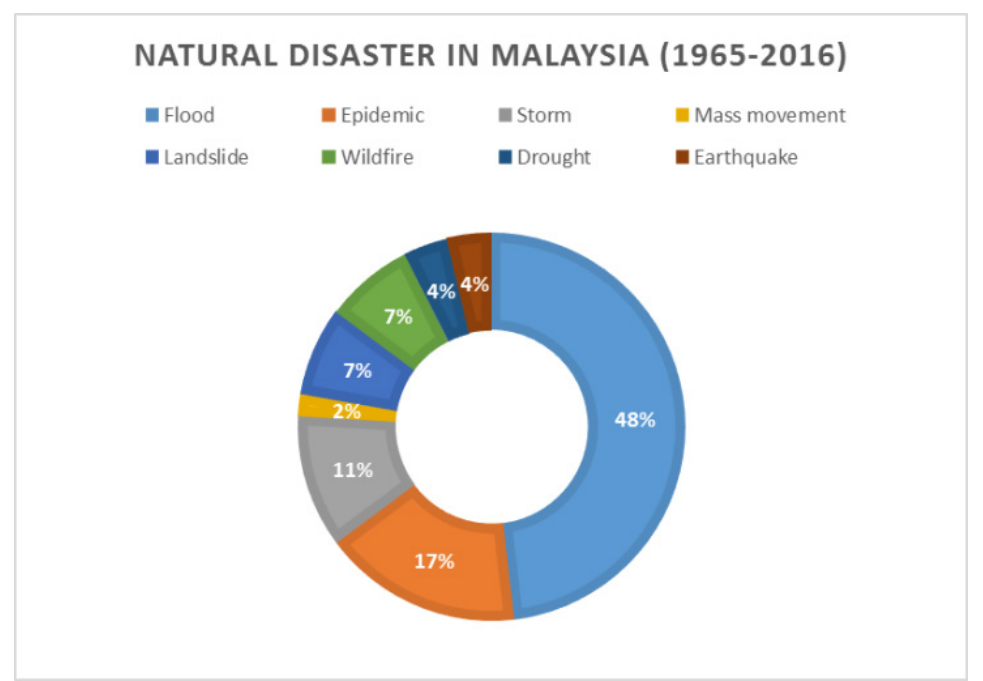

Fig. 1. Frequency of natural disasters that happened in Malaysia from 1965 to 2016 [1].

On December 2014, some parts of Malaysia had been hit with extreme flood, and in some places, it was even recorded as the worst event ever occurred. Perak, a Northern state in Malaysia, was one of the states that were badly affected by flood. In this study, Perak is chosen as the main area for assessment as it involves a unique case - four cascading hydroelectric dams. Among the areas in Perak that had been flooded were Kampung Gajah, Lenggong, Kerian, Bota, Parit, Kuala Kangsar and Sungai Siput.

Generally, the 2014 flooding event in Perak is associated with the overwhelming rainfall affecting the dams along Perak River, which are Temenggor dam, Kenering dam, Chenderoh dam and Bersia dam. During heavy rainfalls event on December 2014, an additional discharge was observed to be released from the dams due to over capacity of water level in the reservoir. Such action was understandably taken to avoid the dams from collapsing which could results in much more severe damage towards the downstream areas. Flooding and destruction happened in Perak because houses and properties were mostly located near river and within flood prone areas. Besides that, the long inundation period of the flood, which was up to one month in some areas, has caused a higher rate of destruction.

In some places, the villagers claimed they never experience flooding before and 2014 flood event was the first flood disaster they have ever encountered. Among the villages mentioned were Taman Murni and Kampung Tersusun Sejagop in Perak Tengah district, Kampung Lintang, Kampung Pulau Mentimun, PPRT Kampung Senggang, Kampung Pulai Ara Panjang and Kampung Biong Sauk in Kuala Kangsar.

\section{Dam pre-release}

This paper further discusses on pre-release concept and how the implementation will help to reduce the flood impact environmentally and economically. Pre-release in this context is defined as the strategic release of water to actively manage the water level in a dam prior to forecast rainfall. There are some countries, which already practiced this pre-release concept, such as Australia and South Africa. They even have pre-release and surcharge 
policy. Most of the dams are mainly for water storage; to supply potable water. Generally, pre-release is introduced to flood control dam. The principles of flood control dam consist of flood absorption and pre-release [2].

\subsection{Melbourne Water, Australia}

The purpose of the Melbourne Water's Dam Pre-Release and Surcharge Policy is to outline the company's practices on the dams pre-release and surcharge. The policy is practical to all the dams, which are under their management, including harvesting dams with or without catchments, seasonable storages and obsolete dams. It covers the Melbourne Water's practices, which are related to the pre-release of water and water level surcharge from the dams.

Melbourne Water is in charge of 16 dams, where each of them has been designed to function as water storage for drinking water source and in certain cases for drainage. All of them have uncontrolled spillways which would allow the dam water level to be maintained below the crest of the dam in case of intense flood situation. However, if the water level is above the spillway, the flow is uncontrollable thus additional discharges will naturally occur during flood events. Despite that, in regular 'non flood' operational situations, Melbourne Water does manage the discharge amount from their dams, as it is part of the environmental flow responsibilities. This is where they take into account the volume of rainfalls received so that the discharge could be well-planned. In term of safety, Melbourne Water always ensures that the stability of the dams are continually observed and they always deliver discharge report to related emergency organizations during flood events.

In managing their dams, Melbourne Water initiates reserved discharges of water from its dams when it is believed compulsory for dam safety purposes. Their dam operation aims to amplify water intake while diminishing hazard to the neighbourhood and assuring conformity with its Bulk Water Entitlements and environmental flow duties [3].

\subsection{South Gippsland Water, Australia}

The South Gippsland Water (SGW)'s Dam Pre-Release and Surcharge Policy is to delineate the operating rules and relevant measures related to pre-release and extra discharge of dams during heavy rainfall events.

SGW maintains their dams by ensuring that measured discharges of water by means of scour passages from the dam will commence when it is considered needed for dam safety purposes. They will amplify water intake while diminishing any possible safety or flood threat to the public and ensuring conformity with environmental flow duties.

Their management policy also specifies measures in reducing possible flood effects. The dams are not designed to discharge vast amount of water, before or during any overflowing. The spillway will make to function when the water level is above FSL where it will allow safe passageway of the overflow. SGW dams which have unrestrained spillways do not have allied flood mitigation guidebooks and therefore it is impossible to control the water release during normal or flood occasions. In utmost flood occasions, the spillways will ensure that the water level is kept below crest of the dam to safeguard the stability of the structure. To establish agreement with environmental flow responsibilities, regulated small discharge from their storages which are prearranged and actively accomplished are frequently made in order to make sure that their action does not commit to flood or riverbank overflows [4]. 


\subsection{Goulburn-Murray Water, Australia}

Implying to predicted inflows, pre-release will be contemplated when the dams have exposure to failing. In determining the amount of water to be pre-released, their utmost policy requires that any volume of water discharged should be replenished with a high degree of reliance. The emphasize is to ensure that the pre-release would not cause any man-made flooding and there is no previous flooding downstream that would be impacted by the pre-release unprepared. Generally, their dam management also focuses so that downstream flood peak can be decreased [5].

\subsection{Orange-Fish-Sundays River Basin, South Africa}

In operating the reservoir for the Orange-Fish-Sundays River Basin in South Africa, MIKE II was used to model and simulate the reservoir operations and river flows. Real-time data was used and optimized for sideways inflow, river water level, salinity and reservoir procedure to make sure the fulfilment of the multiple objectives of the simulationoptimization which includes flood control, hydropower generation and irrigation. The simulation-optimization framework is very flexible because it can be applied to any control parameters and objectives of interest [6].

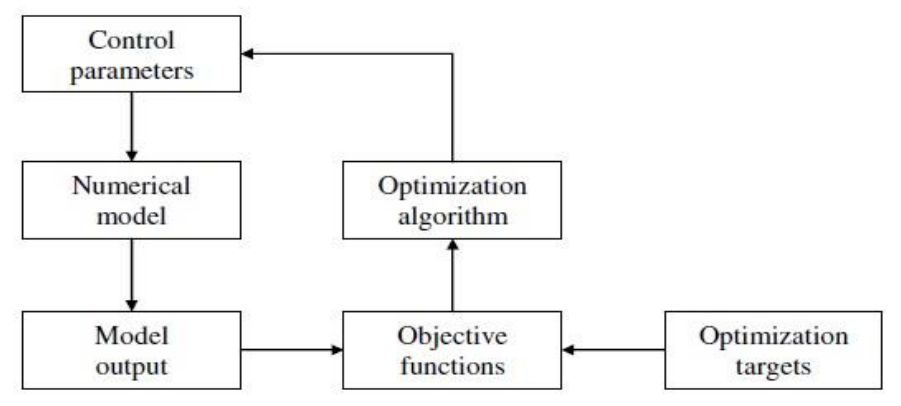

Fig. 2. Simulation-Optimization framework for Orange River Basin, South Africa [6].

As indicated in earlier study, the main objective was to minimise the water loss from the Orange-Fish-Sundays River System and ensure that the irrigation demands were fulfilled [6]. This had also included maintaining the water level in the dam between Minimum Operating Level (MOL) and Full Supply Level (FSL). Under normal operating system, the water level will be kept closed to MOL but under flood events condition, if the forecasted rainfalls would exceed the FSL, pre-release would be executed. From the simulation in the late 2015 and early 2016 on that river basin, it is distinguished that pre-release was executed when the water level reached FSL of the reservoir.

\section{Pre-release concept}

As mentioned above, pre-release has been practiced by some of the countries, but none of them are hydroelectric dam. In Perak, there are four cascading hydroelectric dams, as shown in Fig. 3, comprise of Temenggor Dam, Bersia Dam, Kenering Dam and Chenderoh dam, which are managed by Tenaga Nasional Berhad (TNB). It is naturally expected that TNB's procedure for releasing water is based on electricity demand; as their main service is providing electricity for industrials and also domestic uses. Thus, for hydroelectric dam, 
among the vital criteria that need to be considered in optimizing this concept are the dam level and dam discharge. For hydroelectric dam, these two parameters are crucial because every drop of water that the dam release is crucial for their operation. The dam cannot simply discharge water without proper planning ahead. Fig. 4 shows the basic concept of how the pre-release would work.

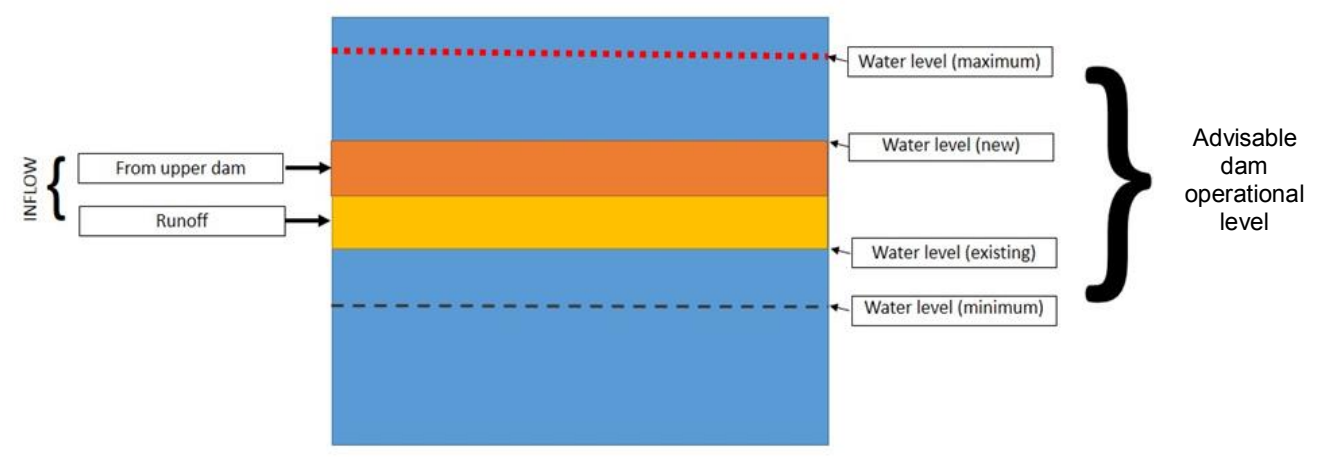

Fig. 3. Cascading dams in Perak (Reproduced from [8]).

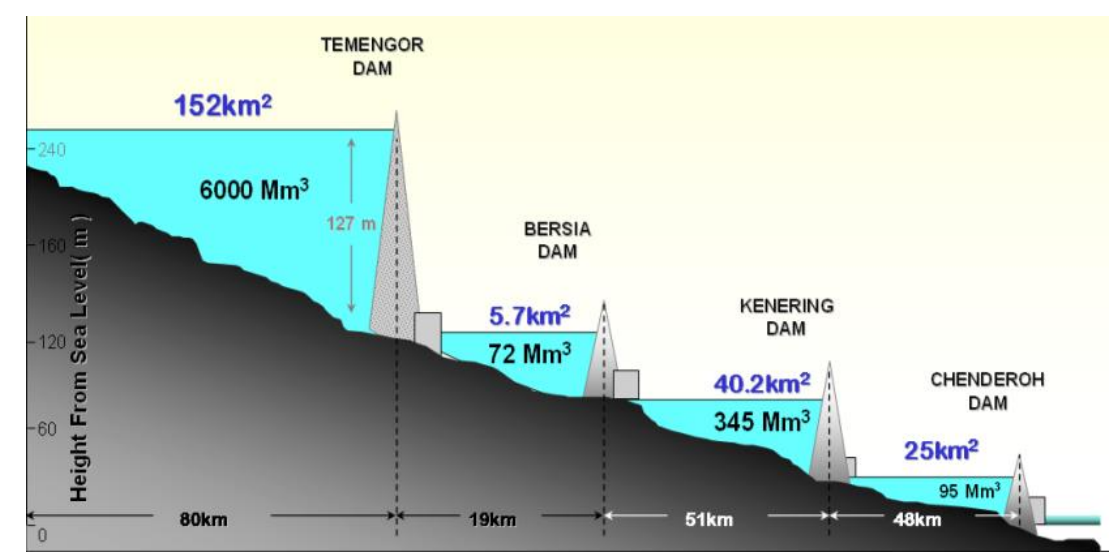

Fig. 4. Advisable dam operational level.

Fig. 4 shows the schematic illustration on dam cross section. The basic concept of prerelease is based on controlling the dam level in between minimum water level and maximum water level. The proposed scheme for volume of water that need to be discharged is:

Volume of water need to be discharged $=$ new storage volume - (forecast inflow from upper dam + forecast runoff)

It is important to ensure that the water level in the dam is maintained at least the minimum required level so as not to affect the operational requirement of the electricity generation. 


\subsection{Pros \& cons of pre-release}

By introducing pre-release into the dam management systems, it also means to allow some risks to the dam. The benefits of implementing pre-release would include the dam level is maintained and monitored throughout the year; so that no excessive water will be discharged during peak rainfall season. Other than that, it will prevent unnatural flooding; flooding due to extra discharge from the dams thus reducing the flood impact to the downstream areas; environmentally and economically (if flood are to happen during monsoon seasons)

\section{Conclusions}

Pre-release is not a new method in the dam management. However, pre-release done by hydroelectric dam would somehow be difficult to handle. In Perak's unique case, the dams are cascading; which the flow from the upper dam will accordingly affect the lower dam. Thus, proper management need to be carried out. Since pre-release is human-controlled, a sound and fail-proof policy would be needed beforehand and sufficient studies and simulation would be required before the implementation, especially when involving hydroelectric dam. Regardless of that, to apply this approach to the cascading hydroelectric dams in Malaysia remains as a challenging task.

The authors also wish to express special thanks to the Centre of Post Graduate Studies and Department of Civil and Environmental Engineering, Universiti Teknologi PETRONAS for their support and encouragement.

\section{References}

1. EM-DAT - The International Disaster Database. Retrieved February $15^{\text {th }} 2017$ from http://www.emdat.be/ [online]

2. J. Jordaan, A. Bell. EOLSS Publications. (2009)

3. "Dam Pre-Release and Surcharge Policy". Retrieved March $14^{\text {th }} 2017$ from https://www.melbournewater.com.au/aboutus/whoweare/Legislationandpolicies/policie s-and-procedures/Documents/Dam\%20prerelease $\% 20$ and $\% 20$ surcharge $\% 20$ policy.pdf [online]

4. "Dam Pre-Release and Surcharge Policy". Retrieved March $14^{\text {th }} 2017$ from http://www.sgwater.com.au/wp-content/uploads/2014/04/Dam-pre-release-andsurcharge-policy.pdf [online]

5. "Policy PRE-RELEASE FROM DAMS". Retrieved March $14^{\text {th }} 2017$ from http://www.g-mwater.com.au/downloads/gmw/Storages/Pre-

Release_from_Dams_Policy.pdf [online]

6. C. B. Pedersen, H. Madsen, C. Skotner. 13th SANCIAHS Symposium (2007)

7. F. Chou, C. Wu, Journal of Hydrology 497, 1-14. (2013)

8. M.I. Najid, L.M. Sidek, B. Hidayah, Z.A. Roseli, International Conference on Advances in Renewable Energy and Technologies (ICARET 2016) (2016) 